\title{
Hubungan Kinerja Kader dengan Kepuasan Pelayanan pada Lansia di Posyandu Cinta Lansia
}

\section{Correlation Performance Cadres with Satisfaction Services Among Elderly in Posyandu Cinta Lansia}

\author{
Emi Suhadak ${ }^{1}$, Arita Murwani ${ }^{2}$ \\ 1. STIKes Surya Global Yogyakarta, Indonesia \\ 2. STIKes Surya Global Yogyakarta, Indonesia \\ *Email Korespondensi : emisuhadak26@gmail.com
}

\begin{abstract}
Abstrak
Latar belakang: Kinerja kader posyandu yang diberikan akan menggambarkan kepuasan pelayanan pada lansia yang dimana dilihat dari tugas yang telah di lakukan oleh kader posyandu. Dengan demikian penulis tertarik untuk mengetahui hubungan kinerja kader dengan kepuasan pelayanan pada lansia di Posyandu Cinta Lansia.

Tujuan: Mengetahui hubungan antara kinerja kader posyandu dengan kepuasan pelayanan pada lansia di Posyandu Cinta Lansia Desa Jambidan.

Metode: Penelitian ini menggunakan desain deskriptif kuantitatif dengan pendekatan cross sectional. Populasi di Posyandu Cinta Lansia terdiri dari 56 lansia dan 35 kader. Penelitian menggunakan teknik pengambilan sampel accidental sampling, dengan jumlah sampel 35 lansia dan 35 kader. Teknik analisa data menggunakan Kendall-Tau. Hipotesis pada penelitian ini ada hubungan antara kinerja kader posyandu dengan kepuasan pelayanan pada lansia di Posyandu Cinta Lansia.

Hasil: Hasil analisis menunjukkan bahwa Kinerja kader posyandu dengan kategori baik $(57,1 \%)$, cukup $(17,1 \%)$, dan kurang $(25,7 \%)$. Kepuasan pelayanan pada lansia dengan kategori baik $(71,4)$, cukup $(17,1 \%)$, dan kurang $(11,4 \%)$. Hasil uji statistik menunjukkan besarnya koefisien korelasi Kendall-Tau yaitu -0,456 dengan signifikasi 0,009. Hal ini menunjukkan bahwa nilai $p<0,05$.

Kesimpulan: Dapat disimpulkan bahwa terdapat hubungan positif dan signifikan antara kinerja kader posyandu dengan kepuasan pelayanan pada lansia di Posyandu Cinta Lansia. Diharapkan peneliti selanjutnya untuk melakukan penelitian terkait faktor komunikasi dan kemampuan motivasi psikologis kader posyandu lansia yang mempengaruhi kepuasan pelayanan pada lansia.
\end{abstract}

Kata kunci: Kader; Kinerja; Lansia; Pelayanan; Posyandu

\begin{abstract}
Background: The performance of the posyandu cadre which is given was described satisfaction service to the elderly which is seen from task had been performed by posyandu cadres. Thus the author is interested to know the correlation between the performance of the posyandu cadres with satisfaction service to the elderly in Posyandu Cinta Lansia.

Objective: Find out the correlation between posyandu cadres with satisfaction service to the elderly in Posyandu Cinta Lansia Jambidan Village.

Method: The research was used as a quantitative descriptive method with a cross-sectional approach. The population in Posyandu Cinta Lansia consists of 56 elderly and 35 cadres. The research uses an accidental sampling technique, with several sampling of 35 elderly and 35 cadres. Data analysis technique using Kendall-Tau's method. The hypothesis from this research, there is a correlation between the performance of posyandu cadre with service satisfaction in the elderly in Posyandu Cinta Lansia.
\end{abstract}

Result: The analysis result showed performance of posyandu cadres with categories, good (57,1\%), enough $(17,1 \%)$, and less $(25,7 \%)$. Service satisfaction to the elderly with categories, good $(71,4 \%)$, 
enough $(17,1 \%)$, and less $(11,4 \%)$. Statistical analysis results showed the value of the Kendall-Tau correlation coefficient is -0456 with the significance of 0,009. This shows that the value of $p<0,05$.

Conclusion: That means there is a positive and significant relationship between the performance of posyandu cadres and service satisfaction to the elderly in Posyandu Cinta Lansia. It's expected to further researchers to do related research about communication factor and posyandu cadres psychological motivation ability that affects service satisfaction to the elderly.

Keywords: Cadre; Elderly; Performance; Posyandu; Service

\section{PENDAHULUAN}

Lansia secara global pada tahun 2013 proporsi dari populasi penduduk berusia lebih dari 60 tahun sekitar 11,7\% dari total populasi di dunia. Hingga saat ini, penduduk di 11 negara yang berada di kawasan Asia Tenggara yang berusia di atas 60 tahun berjumlah 142 juta orang dan diperkirakan akan terus meningkat hingga 3 kali lipat ditahun 2050. Sedangkan di Indonesia sendiri pada tahun 2020 diperkirakan jumlah lansia sekitar 80 juta (1).

Penduduk lansia di Indonesia pada tahun 2017 terdapat 23,66 juta jiwa dan diprediksi jumlah penduduk lansia tahun 2025 mencapai angka 33,69 juta jiwa. Terdapat tiga provinsi dengan presentase lansia terbesar yakni Daerah Istimewa Yogyakarta (DIY) $(13,81 \%)$, Jawa Tengah (12,59\%), dan Jawa Timur (12,25\%) (2).

Tahun 2015 jumlah posyandu lansia di Indonesia sudah tersebar di 23 provinsi. Posyandu lansia terbanyak ada Di Provinsi Jawa Timur yaitu berjumlah 54.522 posyandu lansia sedangkan di DIY ada sekitar 3.280 posyandu lansia (2).

Dalam hadist yang disampaikan oleh Abu Hurairah Radhiyallahu anhu, bahwa sesungguhnya Rasulullah Shallallu'alaihi wa sallam bersabda:" Usia umatku (umat Islam) antara 60 hingga 70 tahun. Dan sedikit mereka yang melewatinya. (HR. At-Tirmidzi dan Ibnu Majah 1073).

Pemerintah telah membuat suatu kebijakan untuk memperhatikan kesehatan lansia. Salah satunya melalui kementrian kesehatan yang membuat peraturan menteri kesehatan Nomor 67 tahun 2015 tentang penyelenggaraan pelayanan kesehatan lansia di Pusat Kesehatan Mayarakat (PUSKESMAS). Puskesmas memiliki berbagai program salah satunya adalah Posyandu lansia, yang dimana posyandu lansia tidak bisa di lepaskan dari kader, karena kualitas kader akan mempengaruhi kepuasan lansia untuk datang ke peleyanan posyandu Berdasarkan studi pendahuluan yang dilakukan oleh peneliti di Puskesmas Banguntapan I pada 23 September 2019, di Puskesmas Banguntapan I memiliki posyandu lansia 29 kelompok posyandu. Di Desa Jambidan memiliki posyandu 9 kelompok dan salah satunya adalah Posyandu Cinta Lansia yang dimana kader dalam melakukan pendataan atau pencatatan tentang pengukur tinggi badan, berat badan, indeks masa tubuh (IMT), kartu menuju sehat (KMS) ke dalam buku register hanya dilakukan setiap pelaksanaan posyandu, diluar pelaksanaan pencatatan dan pendataan lansia jarang dilakukan, sehingga pencatatan kunjungan lansia hanya dicatat berat badan, indeks masa tubuh (IMT. Jumlah lansia yang datang mengalami penurunan dari tahun sebelumnya. Penyuluhan sosial jarang sekali dilakukan oleh kader, penyuluhan hanya dilakukan jika petugas kesehatan datang ke posyandu lansia dan memberikan informasi kepada kader, kegiatan-kegiatan di posyandu lansia hanya tergambar pada proses 5 meja selebihnya tidak ada kegiatan yang bertujuan untuk meningkatkan kesehatan lansia seperti senam yang saat ini tidak pernah diadakan dan penyuluhan. Gambaran diatas menunjukkan bahwa keaktifan kader serta kinerja kader yang masih kurang.

Hal tersebut didukung dengan hasil wawancara dan survei yang dilakukan oleh peneliti dengan 3 kader posyandu dan 5 lansia di Desa Jambidan dan didapatkan hasil bahwa kader 
mengatakan bahwa pelatian kader selama ini dilakukan oleh puskesmas, frekuensi pelatihan sesuai dengan dana yang ada, diluar itu kader jarang mengikuti pelatihan dari luar puskesmas. Wawancara juga dilakukan kepada lansia, sebanyak 2 lansia mengatakan nyaman dengan pelayanan yang diberikan oleh kader, petugas kesehatan lansia juga mengatakan kader jarang melakukan penyuluhan serta pendataan kepada lansia dan 3 lansia mengatakan tidak puas dengan posyandu karena terkadang menunggu lama pada saat posyandu lansia dilaksanakan terutama pada saat pemeriksaan tekanan darah karena hanya dilakukan oleh 1 petugas kesehatan tanpa di bantu oleh kader. Merujuk pada permasalahan yang sudah di paparkan tersebut maka peneliti merasa melakukan penelitihan tertarik untuk melakukan penelitian dengan judul "Hubungan Antara Kinerja Kader Posyandu Dengan Kepuasan Pelayanan Pada Lansia Di Posyandu Cinta Lansia Desa Desa Jambidan Kecamatan Banguntapan Kabupaten Bantul Daerah Istimewa Yogyakarta".

\section{METODE}

Jenis penelitian deskriptif kuantitatif dengan pendekatan Cross Sectional. Populasi pada penelitian ini lansia dan kader yang aktif Di Posyandu Cinta Lansia, sebanyak 56 lansia dan 35 kader. Teknik pengambilan sampel yang digunakan accidental sampling, sampel berjumlah 35 lansia dan 35 kader. Penelitian dilakukan pada 8 Januari 2020. Kinerja kader posyandu adalah hasil kerja atau keberhasilan kader dalam melaksanakan tugas dan tanggungjawabnya yang diukur berdasarkan uraian tugas tugasnya pada saat pelaksanaan posyandu lansia. Pengukuran kinerja kader posyandu lansia menggunakan kuesioner kinerja kader posyandu. Kuesioner ini menggunakan skala guttman. Hasil pengkategorian ini menggunakan skala ordinal dengan kategori sebagai berikut: Kinerja kader baik: 76-100\%, Kinerja kader cukup: 56-75\%, Kinerja kader kurang: $<56 \%$. Kepuasan pelayanan pada lansia adalah kesesuaian harapan lansia sebelum dan sesudah mereka menerima jasa pelayanan posyandu yang diberikan oleh kader posyandu lansia. Alat ukur kepuasan pelayanan menggunakan kuesioner kepuasan pelayanan pada lansia. Kuesioner ini menggunakan skala likert dan responden akan diberikan pertanyaan terkait dengan Faktor keandalan, faktor empati dan faktor kenyataan. Hasil pengkategorian ini menggunakan skala ordinal dengan kategori sebagai berikut: Kepuasan pelayanan baik: 76-100\%, Kepuasan pelayanan cukup: 56$75 \%$, Kepuasan pelayanan kurang: $<56 \%$. Teknik pengumpulan data menggunakan data primer dan data sekunder. Data primer di dapatkan dari kader dan lansia di Posyandu Cinta Lansia, melalui wawancara langsung kepada responden tentang tugas-tugas kader dilakukan dengan baik atau tidak. Data sekunder diperoleh dari jurnal penelitian sebelumnya, data Dinas Kesehatan Bantul dan dari Penanggung jawab Lansia di Puskesmas Banguntapan 1. Penelitian ini menggunakan instrumen kuesioner kinerja kader dan kepuasan pelayanan pada lansia. Kuesioner telah di uji validitas dan reliabilitas oleh peneliti 21 Desember tahun 2019 dengan hasil 15 pernyataan untuk kuesioner kinerja kader dan 15 pernyataan untuk kepuasan pelayanan pada lansia pernyataan valid. Nilai $r r_{\text {hitung }}>r_{\text {tabel }}$, nilai $r_{\text {hitung }} 0,7807$. Hasil reliabilitas dari kinerja kader yaitu 0,987 dan hasil reliabilitas dari kepuasan pelayanan 0,952 untuk nilai alpha cronbach's. Teknik analisa data menggunakan Kendall-Tau. Ethical clearance dilakukan di Universitas Respati Yogyakarta dengan hasil dinyatakan layak melakukan penelitian dengan nomor Ethical clearance No: 383.3/FIKES/PL/XII/2019. 
HASIL

Tabel 1. Distribusi frekuensi kinerja kader di Posyandu Cinta Lansia

\begin{tabular}{|c|c|c|}
\hline Kategori & Frekuensi & Persentase \\
\hline Baik & 20 & 57,1 \\
\hline Cukup & 6 & 17,1 \\
\hline Kurang & 9 & 25,7 \\
\hline Total & 35 & 100 \\
\hline
\end{tabular}

Tabel 2. Distribusi frekuensi kepuasan pelayanan pada lansia di Posyandu Cinta Lansia

\begin{tabular}{lcc}
\hline \multicolumn{1}{c}{ Kategori } & Frekuensi & Persentase \\
\hline Baik & 25 & 71,4 \\
Cukup & 6 & 17,1 \\
Kurang & 4 & 11,4 \\
\hline Total & 35 & 100 \\
\hline
\end{tabular}

Tabel 3. Tabulasi Silang Hubungan antara Kinerja Kader Posyandu dengan Kepuasan Pelayanan pada Lansia di Posyandu Cinta Lansia

\begin{tabular}{ccccccccc}
\hline \multirow{2}{*}{$\begin{array}{c}\text { Kinerja Kader } \\
\text { Posyandu }\end{array}$} & \multicolumn{9}{c}{ Kepuasan Pelayanan Pada Lansia } & \multicolumn{2}{c}{ Total } \\
\cline { 2 - 8 } & \multicolumn{2}{c}{ Kurang } & \multicolumn{2}{c}{ Cukup } & \multicolumn{2}{c}{ Baik } & & \\
\cline { 2 - 8 } & $\mathrm{F}$ & $\%$ & $\mathrm{~F}$ & $\%$ & $\mathrm{~F}$ & $\%$ & $\mathrm{~F}$ & $\%$ \\
\hline Rendah & 18 & 51,4 & 2 & 5,7 & 0 & 0 & 20 & 57,1 \\
Sedang & 2 & 5,7 & 4 & 11,4 & 0 & 0 & 6 & 17,1 \\
Tinggi & 5 & 14,4 & 0 & 0 & 4 & 0 & 9 & 25,7 \\
\hline Total & 25 & 71,4 & 6 & 17,4 & 4 & 11.4 & 35 & 100 \\
\hline
\end{tabular}

Tabel 4. Hasil uji Kendall-Tau antara kinerja kader posyandu dengan kepuasan pelayanan pada lansia di Posyandu Cinta Lansia

\begin{tabular}{lccc}
\hline \multicolumn{1}{c}{ Variabel } & $\begin{array}{c}\text { Koefisien korelasi } \\
\text { Kendall-Tau }\end{array}$ & Nilai Sig. & Keterangan \\
\hline Kinerja kader & $-0,456^{* *}$ & 0,009 & Signifikan \\
\hline Kepuasan pelayanan & & 0,09 & \\
\hline
\end{tabular}

\section{PEMBAHASAN}

Data hasil penelitian pada tabel 1 kinerja kader di Posyandu Cinta Lansia Desa Jambidan Kecamatan Banguntapan Kabupaten Bantul Daerah Istimewa Yogyakarta dapat diketahui bahwa dari 35 responden yang memiliki kinerja kader baik sebanyak 20 responden $(57,1 \%)$, yang memiliki kinerja kader cukup sebanyak 6 responden $(17,1 \%)$, dan yang memiliki kinerja kader kurang sebanyak 9 responden $(25,7 \%)$.

Hasil penelitian diatas menunjukkan bahwa sebagian besar kinerja kader baik. Hal ini dapat dilihat dari kader dalam melakukan tugasnya dengan baik, kader terlihat menjaga sopan santun lansia seperti berbicara dengan lansia menggunakan bahasa jawa halus atau bahasa krama inggil dan dengan nada yang rendah, kader memperhatikan semua lansia dan mengajak komunikasi dalam posyandu sehingga antara kader lansia sudah mengenal satu sama lain.

Peneliti ini juga sejalan dengan penelitian yang dilakukan oleh Faridah (2018) yang menunjukkan bahwa kinerja kader sangat penting dalam pelaksanaan posyandu lansia, sikap serta pelayanan yang diberikan kader menunjukkan kinerja kader. Dalam penelitian lansia ini lansia mengatakan bahwa kader yang aktif memuat lansia merasa nyaman dalam pelaksanaan- 
nya di posyandu lansia sehingga kinerja kader dapat dijadikan sebagai tolak ukur dalam menilai kepuasan pelayanan posyandu lansia (3).

Penelitian yang lain juga mengatakan bahwa kinerja adalah keberhasilan seseorang dalam melaksanakan tugas dan tanggung jawab (4).

Penelitian ini juga sejalan dengan penelitian yang dilakukan oleh Anggraeni (2014) yang mengatakan kinerja kader sangat penting dalam pelaksanaan posyandu lansia, sikap serta pelayanan yang diberikan kader menunjukkan kepuasan pada lansia. Dalam penelitian lansia mengatakan bahwa sikap kader yang ramah serta kegiatan kader yang aktif membuat lansia merasakan kenyamanan dalam pelaksanaan posyandu lansia, sehingga kinerja kader dapat dijadikan sebagai tolak ukur dalam menilai kepuasan pengunjung terutama lansia yang merasakan jasa/pelayanan posyandu lansia (5).

Hasil penelitian lain menyatakan bahwa kinerja kader posyandu memiliki hubungan yang positif terhadap kepuasan lansia sebagai pengguna layanan kesehatan dari Posyandu juga akan meningkat. Dalam posyandu lansia, lansia adalah pengunjung yang langsung merasakan bagaimana posyandu memberikan pelayanan terhadap lansia diamana didalamnya ada peran kader untuk berusaha meningkatkan segala pelayanan serta kegiatan dalam pelaksanaan posyandu lansia sehingga lansia merasakan harapan yang sesuai dengan yang diinginkan (6).

Pada penelitian ini kinerja kader posyandu lansia dengan motivasi lansia mengunjungi posyandu lansia, bahwa hasil pengamatan menunjukkan bahwa sebagian besar $(54,7 \%)$ kinerja kader posyandu termasuk dalam kategori baik. Hal tersebut dikarenakan kader yang terpilih sebagai anggota atau pengurus posyandu merupakan warga yang memang berasal dari lokasi setempat, sehingga sudah mengenal dan paham akan karakteristik masyarakat. Kondisi ini menjadikan kader dapat berinteraksi dengan baik, cerdas, ramah dan berjiwa sosial tinggi dalam memberikan pelayanan kepada lansia. Senada dengan penelitian ini, bahwa kader posyandu lansia Anggrek Bulan juga merupakan warga setempat, sehingga kader dinilai telah memiliki kinerja yang baik kepada lansia. Kinerja kader posyandu yang baik, selain harus handal dalam penanganan juga perlu dilengkapi dengan adanya empati (7).

Kinerja kader juga ditentukan oleh faktor kegiatan yang dilakukan kader, kegiatan yang dilakukan kader sebagai upaya meningkatkan pelayanan pada posyandu lansia, sesuai dengan penelitian yang mengetahui bahwa kegiatan dan pelayanan kader merupakan salah satu faktor yang menjadi tolok ukur kinerja kader (8).

Dari uraian penjelasan diatas dapat disimpulkan bahwa kinerja sangat penting posyandu lansia, sikap dan pelayanan mempengaruhi kinerja kader.

Hasil analisis pada tabel 2 menjelaskan bahwa kepuasan pelayanan pada lansia di Posyandu Cinta Lansia Desa Jambidan Kecamatan Banguntapan Kabupaten Bantul Daerah Istimewa Yogyakarta dapat diketahui bahwa dari 35 responden yang merasa puas dengan pelayanannya baik sebanyak $(71,4 \%)$, yang merasa puas dengan pelayanan-nya cukup sebanyak $(17,1 \%)$ dan yang puas dengan pelayanannya kurang sebanyak $(11,4 \%)$.

Hasil penelitian ini sesuai dengan kinerja kader di Poyandu Cinta Lansia Desa Jambidan Kecamatan Banguntapan Kabupaten Bantul Daerah Istimewa Yogyakarta yang masuk dalam kategori baik, maka kepuasan pelayanan pada lansia di Posyandu Cinta Lansia Desa Jambidan Kecamatan Banguntapan Kabupaten Bantul Daerah Istimewa Yogyakarta juga termasuk ke dalam kategori baik.

Berdasarkan hasil kuesioner yang diisi oleh lansia yang datang di Posyandu Cinta Lansia didapatkan bahwa (71,0\%) kepuasan pelayanan pada lansia di Posyandu Cinta Lansia Desa Jambidan Kecamatan Banguntapan Kabupaten Bantul Daerah Istimewa Yogyakarta dalam kategori baik. Hal ini ditunjukkan oleh adanya kader posyandu bekerja dengan baik dari sebelum hari posyandu lansia. Kader mengingatkan lansia melalui pengeras suara masjid 
bahwa posyandu lansia akan dilaksanakan pada hari X, setelah lansia datang ke posyandu, kader sudah melakukan pola lima meja.

Tugas kader terbagi menjadi tiga kegiatan. Kegiatan pertama: Melakukan kegiatan bulanan posyandu seperti: Kader menyiapkan alat dan bahan, yaitu alat penimbangan, KMS, alat peraga, alat pengukur bahan/materi penyuluhan, kader mengundang dan menggerak-kan masyarakat, yaitu memberitahu para lansia untuk datang ke posyandu, kader menghubungi kelompok kerja (POKJA) posyandu dengan menyampaikan rencana kegiatan kepada kantor desa dan meminta mereka untuk memastikan apakah petugas sektor bisa hadir pada hari buka posyandu, kader melaksana-kan pembagian tugas, yaitu menentu-kan pembagian tugas diantara kader posyandu baik untuk persiapan maupun pelaksanaan kegiatan, kader melakukan pendaftaran lansia, kader melakukan pengukuran dan penimbangan berat badan lansia, kader melakukan pencatatan tentang pengukuran tinggi badan dan berat badan, indeks masa tubuh (IMT), dan mengisi kartu menuju sehat (KMS) lansia, kader melakukan penyuluhan, konseling, pelayanan pojok gizi serta pemberian makanan tambahan (PMT) lansia dan pemeriksaan tekanan darah, gula darah, kolesterol dan lain-lain, kader melakukan pemeriksaan kesehatan dan pengobatan, mengisi data-data hasil pemeriksaan kesehatan pada kartu menuju sehat (KMS) dan diharapkan setiap kunjungan para lansia dianjurkan untuk selalu membawa kartu menuju sehat (KMS) lansia guna memantau status kesehatannya, kader memindah-kan catatan-catatan dalam kartu menuju sehat (KMS) ke dalam buku register atau buku bantu kader, kader menilai (mengevaluasi) hasil kegiatan dan merencanakan kegiatan hari posyandu pada bulan berikutnya, kader melakukan kegiatan kunjungan rumah (penyuluhan seseorang) merupakan tindak lanjut dan mengajak para lansia datang ke posyandu pada kegiatan bulan berikutnya.

Kegiatan kedua: menggerakkan masyarakat untuk menghadiri dan ikut serta dalam kegiatan posyandu: kader menggerakkan langsung ke tengah masyarakat, kader menggerakkan melalui tokoh masyarakat atau pemuka agama atau adat. Kegiatan ketiga: kader membantu petugas kesehatan dalam pendaftaran, penyuluhan dan berbagai usaha kesehatan masyarakat lainnya, termasuk pelaksanaan senam lansia. ${ }^{9}$

Hasil penelitian ini sejalan dengan penelitian yang dilakukan oleh Anggraeni (2014) yang mengatakan bahwa kepuasan yang dirasakan lansia terhadap posyandu lansia merupakan suatu bentuk evaluasi terhadap kinerja suatu posyandu dan sebagai bentuk penilaian lansia terhadap pelayanan yang dirasakan (5).

Hasil penelitian menunjukkan bahwa ada beberapa lansia yang menyatakan kurang puas karena tempat tinggalnya yang jauh dari posyandu lansia, selain itu karena kurangnya penyampaian informasi petugas kesehatan tentang peraturan dan prosedur pelaksanaan pelayanan posyandu (10).

Menurut Faridah (2018) Faktor-faktor yang mempengaruhi kepuasan pelayanan pada lansia adalah faktor keandalan empati dan kenyataan merupakan faktor yang berpengaruh terhadap tingkat kepuasan pelayanan pada lansia. Keandalan dan kenyataan dalam penelitian ini meliputi pernyataan yang menggambarkan kemampuan kader dalam melakukan pelayanan serta kegiatan pada saat posyandu lansia serta fasilitas dan kegiatan yang dirasakan lansia dalam pelaksanaan posyandu (3). Faktor-faktor tersebut diinterpretasikan dalam pernyataan kader yang menggambarkan bagaiamana kader dalam melakukan pelayanan, kecepatan kader dalam menanggapi keluhan lansia, cara kader dalam memprioritaskan lansia dalam memberikan pelayanan, informasi-informasi yang diberikan kader terkait kesehatan serta kondisi yang dirasakan lansia terhadap posyandu lansia seperti kenyamanan, kebersihan posyandu lansia serta fasilitas yang didapatkan lansia pada saat pelaksanaan posyandu lansia (5). 
Empati dalam penelitian ini merupakan aspek yang berpengaruh dalam kinerja, empati disini meliputi pernyataan yang menggambarkan bagaimana kader memberikan perhatian kepada lansia dalam kegiatan posyandu lansia, sikap ramah serta cara kader berkomunikasi kepada lansia, serta pernyataan kader yang menggambarkan tentang cara kader dalam memperhatikan kesehatan lansia sehingga lansia merasakan empati yang kader berikan dan lansia pun merasa nyaman dan puas dengan kinerja yang dilakukan kader (11).

Kepusan adalah tanggapan seseorang terhadap kesesuaian tingkat kepentingan dan harapan sebelum mereka menerima jasa pelayanan dengan sesudah pelayanan yang mereka terima. Kepuasan pelayanan kesehatan dapat disimpulkan sebagai selisih kinerja institusi pelayanan dengan harapan pasien atau lansia (4).

Analisa deskriptif kinerja kader posyandu dengan kepuasan pelayanan pada lansia di Posyandu Cinta Lansia di Desa Jambidan Kecamatan Banguntapan Kabupaten Bantul Daerah Istimewa Yogyakarta.

Hasil analisis deskriptif dari tabel 3 dapat dicermati bahwa antara kinerja kader posyandu dengan kepuasan pelayanan pada lansia di Posyandu Cinta Lansia Desa Jambidan Kecamatan Banguntapan Kabupaten Bantul Daerah Istimewa Yogyakarta memiliki kinerja kader yang baik dengan kepuasan pelayanan pada lansia yang baik dengan persentase 51,4\%, kinerja kader cukup dengan kepuasan pelayanan pada lansia baik sebesar 5,7\%, dan kinerja kader kurang dengan kepuasan pelayanan pada lansia baik sebesar 14,4\%.

Hasil penelitian menunjukkan bahwa semakin baik kinerja kader posyandu maka akan semakin baik kepuasan pelayanan yang diberikan kepada lansia. Apabila dianalisa lebih lanjut dari hasil analisa bivariat yang ada maka kinerja kader posyandu yang dilakukan oleh kader ketika melakukan tugas-tugasnya dengan baik dapat mempengaruhi pelayanan yang baik pada lansia termasuk salah satunya yaitu meningkatkan kepuasan pelayanan pada lansia. Kinerja kader posyandu dapat memberikan dampak yang sangat positif kepada lansia untuk mendatangi posyandu selanjutnya.

Kinerja kader baik akan mempengaruhi kepuasan pelayanan, karena dalam mengukur sebuah mutu pelayanan kinerja petugas pun didalamnya akan menjadi salah satu ukuran penilaian untuk menentukan kepuasan lansia, apakah kinerja yang diberikan sesuai dengan standar etik serta memberikan kepusan bagi lansia atau penduduk sekitarnya (12).

Faktor yang mempengaruhi kinerja kader adalah hubungan usia seseorang dapat memutuskan menjadi kader posyandu dengan matang sehingga keputusan yang matang tersebut dapat menjadikan kader posyandu dapat konsisten menjalankan tugas-tugasnya, pengetahuan yang dimana kader mempunyai pengetahuannya yang baik tentang pemahamannya mengenai posyandu lansia, sikap terhadap reaksi seseorang terhadap stimulus atau objek yang tersusun dari berbagai tingkatan yaitu menerima, merespon, menghargai, dan bertanggungajawab, motivasi datang dari dalam pribadi itu sendiri, imbalan kompensasi yang diterimanya atas jasa yang diberikan kepada organisasi, kepemimpinan gaya norma perilaku yang ditujukan seseorang atau yang digunakan seseorang pada saat tersebut mencoba mempengaruhi perilaku orang lain (13).

Hal ini sejalan dengan penelitian yang dilakukan oleh Latuopo et al (2016), yang mengatakan bahwa ada hubungan baik antara kinerja kader yang dilaksanakan di posyandu lansia dengan kepuasan pelayanan pada lansia hal ini dapat dilihat dari beberapa indikator kinerja kader diantaranya kader datang tepat waktu kehadiran diposyandu, aktif dalam memberikan layanan dalam setiap kegiatan posyandu, aktif dalam memberikan penyuluhan, mampu mendengarkan keluhan dan merespon keluhan lansia dengan sangat baik dan cepat (14).

Hasil penelitian diatas juga didukung oleh teori yang dikemukakan oleh Mangkunegara (2010) yang menyatakan bahwa kinerja yang bagus memberikan pengaruh terhadap kepuasan. 
Berdasarkan hasil penelitian ini maka kinerja kader posyandu lansia harus lebih bagus sehingga memberikan tingkat kepuasan pada lansia pada tingkat sangat puas, hal yang dianggap yang perlu diperhatikan adalah dengan meningkatkan kemampuan kader posyandu lansia dalam melaksanakan tugas-tugasnya (14).

Berdasarkan hasil penelitian ini maka kinerja kader posyandu lansia harus lebih bagus sehingga memberikan tingkat kepuasan pada lansia pada tingkat sangat puas, hal yang dianggap yang perlu diperhatikan adalah dengan meningkatkan kemampuan kader posyandu lansia dalam melaksanakan tugas-tugasnya (14).

Hasil penelitian ini sesuai dengan penelitian yang dilakukan oleh Pitoyo et al (2017) yang menemukan hubungan yang positif antara kinerja kader posyandu dengan kepuasan pada lansia dimana semakin baik kinerja kader posyandu maka kepuasan lansia sebagai pengguna layanan kesehatan dari posyandu juga akan meningkat. Dalam posyandu lansia, lansia adalah pengunjung yang langsung merasakan bagaimana kinerja kader posyandunya dalam memberikan pelayanan terhadap lansia, dimana didalamnya ada peran kader untuk berusaha meningkatkan segala pelayanan serta kegiatan dalam pelaksanaan posyandu lansia sehingga lansia merasakan harapan yang sesuai dengan yang diinginkan (6).

Penelitian yang serupa dilakukan oleh Saraisang at al (2018) yang mengatakan bahwa kinerja kader posyandu sangat mempengaruhi kepuasan lansia, dengan melihat jumlah ratarata kehadiran selama 3 bulan terakhir lansia yang mengikuti kegiatan posyandu lansia di puskesmas Ranomuut Kecamatan Paal II Kota Manado. Saat dilihat dari 3 tahun yang terakhir lansia rata-rata ikut maka bisa dikatakan bahwa kinerja kader posyandu mempengaruhi kepuasan lansia (15).

Hasil penelitian yang dilakukan oleh Darmanto et al (2015) yang mengemukakan bahwa kinerja kader posyandu dapat mempengaruhi motivasi lansia mengunjungi posyandu lansia yang dimana motivasi lansia dipengaruhi oleh faktor internal maupun faktor eksternal. Faktor internal seperti kurangnya dukungan dari keluarga, pengetahuan lansia tentang manfaat posyandu lansia yang masih rendah serta masih rendahnya kesadaran lansia tentang pentingnya melakukan pemeriksaan kesehatan. Faktor ekternal yang mempengaruhi motivasi lansia adalah lingkungan yang tidak mendukung seperti jarak rumah dengan lokasi posyandu lansia yang jauh dan waktu atau jadwal yang tidak sesuai dengan waktu lansia. Jarak posyandu lansia yang dekat akan membuat lansia mudah menjangkau posyandu lansia tanpa harus mengalami kelelahan dan kecelakaan fisik karena penurunan daya tahan atau kekuatan fisik tubuh (7).

Kepuasan lansia di Posyandu Cinta Lansia sudah baik karena kader lansia sudah melakukan tugasnya dengan baik dengan melakukan komunikasi yang baik dengan lansia mulai dari sebelum posyandu lansia hingga setelah posyandu lansia seperti mengundang lansia untuk datang kembali ke posyandu setiap tanggal yang sudah ditentukan. Kegiatan dalam posyandu lansia juga sudah berjalan dengan baik, karena didukung dengan alat-alat yang udah tersedia. Harapan lansia sudah terpenuhi namun masih perlu untuk ditingkatkan seperti kader sudah ber-komuniksi dengan lansia dengan tutur kata sopan dan nada yang rendah, kader dan lansia sudah saling mengenal sejak lama sehingga terjadi hubungan saling percaya antara keder dengan lansia.

Hasil korelasi Kendall-Tau pada tabel 4 menunjukkan bahwa ada hubungan positif dan signifikan antara kinerja kader posyandu dengan kepuasan pelayanan pada lansia di Posyandu Cinta Lansia Desa Jambidan Kecamatan Banguntapan Kabupaten Bantul Daerah Istimewa Yogyakarta, dengan hasil analisis korelasi menggunakan Kendall-Tau dengan didapatkan hasil sebesar -0,456 dengan hasil $\mathrm{p}$ value sebesar 0,009, artinya nilai $\mathrm{p}<0,05$ sehingga $\mathrm{H}_{\mathrm{a}}$ diterima dan $\mathrm{H}_{\mathrm{o}}$ ditolak. 
Koefisien korelasi Kendal-Tau dapat diberlakukan dimana melakukan uji signifikansi dengan menggunakan rumus z. Hasil hitung nilai z diperoleh bahwa nilai Zhitung sebesar 0,456, sehingga $\mathrm{H}_{\mathrm{a}}$ diterima dan $\mathrm{H}_{0}$ ditolak. Berdasarkan hasil tersebut maka koefisien korelasi Kendal-Tau dapat disimpulkan bahwa korelasi antara kinerja kader posyandu perawat dengan kepuasan pelayanan pada lansia -0.456 adalah signifikan dan dapat diberikan pada sejumlah sampel penelitian.

Penelitian yang dilakukan oleh Wibowo (2017) menunjukkan hasil uji statistik menggunakan rumus spearman rank yaitu 0,401 dengan nilai $\mathrm{p}$ value 0,001 sehingga dikatakan kinerja kader yang dilakukan kader memiliki hubungan yang signifikan dalam kepuasan pelayanan pada lansia.(4) Penelitian lain yang dilakukan oleh Latuapo (2016) menunjukkan hasil uji statistik menggunakan spearman rank nilai signifikansi $\mathrm{p}=0,000$ sehingga dikatakan kinerja kader posyandu memiliki hubungan dengan kepuasan pelayanan pada lansia (14).

\section{SIMPULAN}

Ada hubungan antara kinerja kader posyandu dengan kepuasan pelayanan pada lansia di Posyandu Cinta Lansia Desa Jambidan Kecamatan Banguntapan Kabupaten Bantul Daerah Istimewa Yogyakarta.

\section{SARAN}

Bagi kader posyandu lansia di Posyandu Cinta Lansia Desa Jambidan Kecamatan Banguntapan Kabupaten Bantul Daerah Istimewa Yogyakarta dalam pelaksanaan posyandu sudah cukup baik.

Bagi lansia dan keluarga di Posyandu Kecamatan Banguntapan Kabupaten Bantul Daerah Istimewa Yogyakarta hasil penelitian ini diharapkan dapat memberikan pengetahuan pada lansia dan membuat lansia puas dengan pelayanan yang dilakukan oleh kader.

Bagi Peneliti selanjutnya diharapkan untuk melakukan penelitian terkait faktor-faktor yang mempengaruhi lansia memanfaatkan posyandu lansia.

\section{UCAPAN TERIMA KASIH}

Peneliti menyampaikan terimakasih kepada Penanggung Jawab Puskesmas Banguntapan I, responden penelitian dan Posyandu Cinta Lansia Desa Jambidan Kecamatan Banguntapan Kabupaten Bantul Daerah Istimewa Yogyakarta yang telah memberikan ijin dan bersedia menjadi responden penelitian.

\section{DAFTAR PUSTAKA}

1. World Health Organization (WHO). Elderry. 2017. Available from: https://www.who.int/mediacentral/factsheets/fs307/en

2. Kementrian Kesehatan Republik Indonesia. Analisis lansia Indonesia. 2017. Available from: https://www.depkes.go.id.pdf

3. Faridah. Hubungan Kinerja Kader Terhadap Kepuasan Lansia dalam Mengoptimalkan Posyandu Lansia di Wilayah Puskesmas Muara Kumpeh di Desa Pudak. Scientia Journal 2018. (7):1-10. Available from: https://scientiajournal.univesitasadiwangsajambi.ac.id/index.php.jkp/article/view/8029

4. Wibowo. Hubungan Antara Kinerja Kader Posyandu Lansia Posyandu Terhadap Tingkat Kepuasan Lansia Di Posyandu Lansia Wilayah Tamantirto. Skripsi. Fakultas Kedokteran Dan Ilmu Kesehatan Universitas Muhammadiyah Yogyakarta. 2017. Available from: http://repository.umy.ac.id/handle/123456789/15635

5. Anggraeni. Hubungan Antara Kinerja Kader Posyandu Lansia Terhadap Kepuasan Lansia dikelurahan Rempoa Wilayah Binaan Kerja Puskesmas Ciputat Timur. Skripsi. Fakultas 
Kedokteran dan Ilmu Kesehatan. Universitas Islam Negeri Syarif Hidayatullah Jakarta. 2014. Available from: https://repository.ac.id.uinsyarifhidayatullahjakarta.pdf

6. Pitoyo, Santuso, Saragih. Kinerja Kader Posyandu dan Kepuasan Lansia, Informasi Kesehatan Indonesia. 2017. 3(1): 36-42. Available from: https://www.journalkemenkesmalang.ac.id/index.php.pdf

7. Darmanto, Arneliwati, Woferst. Hubungan Kinerja Kader Posyandu Lansia Dengan Motivasi Lansia Mengunjungi Posyandu Lansia. Jurnal Online Mahasiswa Program Studi Ilmu Keperawatan Universitas Riau. 2015. 2(1). Available from: https://www.neliti.com/id/publications/187518/hubungan-kinerja-kader-posyandu-lansiadengan-motivasi-lansia-mengunjungi-posyan

8. Mathis and Jackson. Human Resource Management South Westren Cengage Learning.Edisi 13. University of Nebraska at Omaha, University of Wyoming. 2013

9. Ismawati Cahyo Sulityorini, Pebriyanti Sandra, Proverawati Atikah. Posyandu \& Desa Siaga. Edisi II. Yogyakarta. 2015.

10. Siahaan, N. R. Pelaksanaan Program Pelayanan Posyandu Lansia Dan Tingkat Kepuasan Lansia Pengguna Posyandu di Puskesmas Buntu Raja Kecamatan Siempat Nempu $\begin{array}{llll}\text { Kabupaten } & \text { Dairi. } 2014 . & \text { Available }\end{array}$ http://repository.usu.ac.id/handle/123456789/39919

11. Muninjaya GDE. Manajemen Mutu Pelayanan Kesehatan. Edisi 2. Jakarta: Buku Kedokteran EGC. 2019

12. Depkes RI. Pedoman Umum Pengelolaan Posyandu. Jakarta: POKJAL. 2011.

13. Supriyanto. Faktor-Faktor Yang Mempengaruhi Kinerja Kader Kepuasan Lansia. Jurnal Ilmiah Kesehatan. 2017. 6(2) 1-8. Available from: https://www.researchgate.net/publication/334650563_Faktorfaktor_Yang_Mempengaruhi_Kinerja_Kader_Posyandu_Lansia

14. Latuapo, Sutrianingsih, Rahayu. Hubungan Kinerja Kader Dengan Kepuasan Lansia Di Posyandu Lansia Permadi Kelurahan Tlogomas Kota Malang. Nursing News: Jurnal Ilmiah Keperawatan. 2016. 2(1). Available from: https://publikasi.unitri.ac.id/index.php/fikes/article/view/418

15. Saraisang, Kumaat, Katuuk. Hubungan Pelayanan Posyandu Lansia Dengan Tingkat Kepuasan Lansia Di wilayah Kerja Puskesmas Ranomuut Kecamatan Paal II Kota Manado. E-journal Keperawatan. 2018. Available from: https://ejournal.unsrat.ac.id/index.php/jkp/article/view/18770 